\title{
Evaluation of the p16 and Ki-67 Biomarkers as Predictors of the Recurrence of Premalignant Cervical Cancer Lesions after LEEP Conization
}

\section{Avaliação dos biomarcadores p16 e Ki-67 como preditores de recidivas de lesões pré-cancerígenas do colo do útero após conização por cirurgia de alta frequência}

\author{
Paulo Macêdo de Oliveira Leite ${ }^{1}$ Luciene Tafuri ${ }^{1}$ Maria Zélia de Oliveira Costa ${ }^{2}$ \\ Maria Inês de Miranda Lima ${ }^{1}$ Renata Toscano Simões ${ }^{1}$ \\ ${ }^{1}$ Instituto de Ensino e Pesquisa, Santa Casa Belo Horizonte (IEP/SCBH), \\ Belo Horizonte, Minas Gerais, Brazil \\ 2 Hospital São João de Deus, Fundação Geraldo Corrêa, Divinópolis, \\ Minas Gerais, Brazil \\ Address for correspondence Paulo Macêdo de Oliveira Leite, MSc, \\ Instituto de Ensino e Pesquisa, Santa Casa Belo Horizonte (IEP/SCBH), \\ Rua Rio de Janeiro 324/704, 35500-009 Divinópolis, MG, Brazil \\ (e-mail: paulomoleite@gmail.com).
}

Rev Bras Ginecol Obstet 2017;39:288-293.

\begin{abstract}
Objective To evaluate the expressions of biomarkers p16 and $\mathrm{K}_{\mathrm{i}}-67$ in low-grade (LG) or high-grade (HG) lesions, and to relate them to risk factors and the recurrence of these lesions.

Methods A retrospective case-control study of 86 patients with LG and HG lesions who underwent a loop electrosurgical excision procedure (LEEP) between 1999 and 2004. The control group was composed of 69 women with no recurrence, and the study group, of 17 patients with recurrence. All patients were followed-up over a two-year period after surgery, and screened every six months, including cytology and colposcopy. Biopsy samples collected from LEEP were submitted to immunohistochemical analysis for p16 and $\mathrm{K}_{\mathrm{i}} \mathrm{-67}$. The statistical analysis was performed using the Statistical Package for the Social Sciences software (SPSS, IBM-SPSS, Inc., Chicago, IL, US), with a significant $p<0.05$.

Results The biomarkers $\mathrm{p} 16$ and $\mathrm{K}_{\mathrm{i}}-67$, separately or combined, showed no relation to recurrence on the total analysis. However, evaluating specifically HG lesions, the positive expression $(2+$ and $3+)$ of $\mathrm{p} 16 / \mathrm{K}_{\mathrm{i}}-67$ was associated with recurrence $(0.010)$. In

Keywords

- biomarkers

- conization

- cervical intraepithelial neoplasia

- recurrence addition, p16 isolated was also more expressive in $\mathrm{HG}$ lesions $(2+$ and $3+, p=0.018)$, but it was unrelated to recurrence.

Conclusion Proteins p16 and $\mathrm{K}_{\mathrm{i}}-67$, both isolated and combined, are not reliable primary markers for the recurrence of cervical lesions in the majority of LG lesions. However, analyzing only the group with prior diagnosis of HG lesions, the expressions of $\mathrm{p} 16$ and of $\mathrm{p} 16 / \mathrm{K}_{\mathrm{i}}-67$ were associated with recurrence, and they may be useful in monitoring these cases.
\end{abstract}

received

June 12, 2016

accepted

December 15, 2016

published online

February 23, 2017
Copyright $\odot 2017$ by Thieme Revinter

Publicações Ltda, Rio de Janeiro, Brazil
License terms

(c) (i) $\ominus \$$ 


\section{Resumo \\ Palavras-chave \\ - biomarcadores \\ - conização \\ - neoplasia intraepitelial cervical \\ - recidiva \\ Objetivo Avaliar as positividades dos biomarcadores p16 e $\mathrm{K}_{\mathrm{i}}-67$ em lesões de baixo grau (BG) ou de alto grau (AG), e relacioná-las com os fatores de risco e com a recidiva dessas lesões. \\ Métodos Estudo retrospectivo caso-controle, com 86 pacientes com lesões de BG e AG, submetidas à conização por cirurgia de alta frequência entre 1999 e 2004. O grupo de controle foi constituído de 69 mulheres sem recidivas, e o grupo de estudo, de 17 pacientes que recidivaram. Todas as pacientes foram acompanhadas durante dois anos após a cirurgia, com controle a cada seis meses, incluindo citologia e colposcopia. As peças provenientes de cirurgia de alta frequência (CAF) foram submetidas a imuno- histoquímica para p16 e $\mathrm{K}_{\mathrm{i}}-67$. A análise estatística foi realizada com o programa Statistical Package for the Social Sciences (SPSS, IBM-SPSS, Inc., Chicago, IL, EUA), com $p$ significante quando $<0,05$. \\ Resultados Isoladamente ou em conjunto, p16 e $\mathrm{K}_{\mathrm{i}}-67$ não se relacionaram com as recidivas quando analisados na totalidade dos casos. Entretanto, avaliando especifica- mente as lesões de $A G$, a positividade $\left(2+\right.$ e $3+$ ) do conjunto $p 16 / K_{i}-67$ foi relacionada com recidiva $(0,010)$. No mais, $p 16$, isoladamente, foi também mais expresso nas lesões de $\mathrm{AG}(2+\mathrm{e} 3+, p=0,018)$, mas sem relação com recidiva. \\ Conclusão Quando testadas na totalidade dos casos, as proteínas p16 e $\mathrm{K}_{\mathrm{i}}-67$, separadas ou em conjunto, se mostraram ineficientes como marcadores primários de recidiva de lesões precursoras. Entretanto, quando avaliadas somente no grupo diagnóstico prévio de lesão de $A G$, as expressões das proteínas p16 e p16/Ki-67 têm relação com a recidiva, e podem ser úteis no acompanhamento desses casos.}

\section{Introduction}

The search for markers to facilitate the diagnosis of diseases is a constant in scientific research to save resources, time and to prevent unnecessary treatments. Cervical cancer is the most common cancer among women in 45 countries of the world and, worldwide, 266 thousand women die of it each year; ${ }^{1}$ it is preceded by cervical lesions that may or may not progress to invasion. They are associated with infection and with the persistence of the human papillomavirus (HPV) to progress to invasive carcinoma. ${ }^{2}$ Through this process, the cells infected with high-risk oncogenic HPV alter the cell cycle, modifying the production of proteins $\mathrm{p} 16$ and $\mathrm{K}_{\mathrm{i}}-67$. The most common treatment for high grade (HG) lesions is cervical cone resection using the loop electrosurgical excision procedure (LEEP). A major concern of the treatment is the recurrence of the lesion, as it may reappear without symptoms and more severely.

Proteins p16 and $\mathrm{K}_{\mathrm{i}}-67$ are, respectively, cell progression and proliferation markers. Protein p16 is a tumor suppressor from the Ink4a family that induces the hyperphosphorylation of the retinoblastoma protein ( $\mathrm{pRb}$ ), and has low expression in normal tissues. ${ }^{3} \mathrm{~K}_{\mathrm{i}}-67$ is a nuclear protein present in cells during the active proliferation stage, but it is not expressed when cells are in the quiescent state. ${ }^{3}$ The expression of both molecules simultaneously already denotes some problem in the cell cycle. ${ }^{4}$ The main objective of this study was to compare the expression of p16 and $\mathrm{K}_{\mathrm{i}}-67$, individually or combined, with the recurrence of cervical cancer precursor lesions after a LEEP procedure and, also, to verify whether other factors contributed to this.

\section{Methods}

The study was approved by The Ethics and Research Committee of Instituto de Ensino e Pesquisa, Santa Casa Belo Horizonte (no. 1.222.448), and only patients who agreed and signed the informed consent form (ICF) participated.

\section{Sample Selection and Patient Monitoring}

A total of 86 cases of cervical intraepithelial neoplasia (CIN) were evaluated, having been diagnosed by histopathology after LEEP surgery. The sample group was monitored from January 1999 to March of 2004 at a municipal healthcare center in the city of Belo Horizonte. All patients were re-evaluated every 6 months by oncotic cytology, colposcopy and cervical biopsy, when indicated, and followed-up during 2 years to assess whether or not there was lesion relapse.

The total sample of 86 patients consisted of 17 patients with CIN1, 11 with CIN2, and 58 with CIN3. Of the total, 17 presented lesion recurrence. The study group was composed of the 17 recurrences, and the control group, of the other 69 patients. Apart from the biomarkers, both groups were evaluated considering sociodemographic data, previous health status and histological variables. 


\section{Immunohistochemical Markers}

To evaluate p16 and $\mathrm{K}_{\mathrm{i}}-67$ expression levels, immunohistochemistry was performed using monoclonal antibody MIB 1 (Dako) for the $K_{\mathrm{i}}-67$ in the dilution of $1: 100$, and G175-405 (Zeta) in the dilution of 1:100 for the p16. Both antigens were detected using HiDef Detection System, HRP Polymer System (Cell Marque, Rocklin, USA). All immunohistochemical studies were performed in the laboratory of Instituto Moacyr Junqueira, in Belo Horizonte, according to standard protocols.

The readings were done by two independent examiners who classified the slides according to the percentage of positive cells, as described by Zhong et $\mathrm{al}^{5}$ ( $\boldsymbol{-}$ Table $\mathbf{1}$ ).

\section{Statistical Analysis}

Numerical variables were tested for normality (KolmogorovSmirnov test) and the Student's t-test was used in the calculations. At first, the analysis focused on the whole sample characteristics using tables of frequency for the categorical variables, and descriptive measures (mean, median, 25th and 75th percentiles, minimum-value, maximumvalue and standard deviation) for the quantitative variables. Sociodemographic, health and histopathologic variables and their relationship with recurrence, $\mathrm{p} 16$ and $\mathrm{K}_{\mathrm{i}}-67$ positivity, the margin compromise in LEEP etc. were analyzed by the Chi-Square Test. When necessary, Fisher's Test was applied. In all tests, the significance level was of $5 \%$. The statistical analyses were performed using the Statistical Package for the Social Sciences (SPSS, IBM-SPSS, Inc., Chicago, IL, US) software, version 20.0 .

\section{Results}

The sociodemographic variables evaluated were age, parity, first intercourse, number of partners and smoking. They were equally distributed in the two groups, and no statistical significance was detected.

The histological factors for glandular involvement and compromised surgical margins had increased expression in HG lesions ( $p=0.018$ and $p=0.039$ respectively, - Table 2 ). On the other hand, relevant associations with recurrence were found when evaluating the risk factors for human immunodeficiency virus (HIV) positivity (odds ratio [OR]: $0.31 ; 95 \%$ confidence interval $[95 \% \mathrm{Cl}]$ : $0.135-0.937$; $p=0.033)$ and glandular involvement in cervical lesions

Table 1 p16 and $\mathrm{K}_{\mathrm{i}}-67$ positivity according to the percentage of positivity

\begin{tabular}{|l|l|l|l|l|}
\hline Marker & \multirow{2}{*}{ Negative } & $\begin{array}{l}\text { Low } \\
\text { positive }\end{array}$ & $\begin{array}{l}\text { Moderately } \\
\text { positive }\end{array}$ & $\begin{array}{l}\text { High } \\
\text { positive }\end{array}$ \\
\cline { 3 - 5 } & & +1 & +2 & +3 \\
\hline $\mathrm{p} 16^{*}$ & $<5 \%$ & $5-25 \%$ & $26-50 \%$ & $>50 \%$ \\
\hline $\mathrm{K}_{\mathrm{i}}-67^{* *}$ & $<5 \%$ & $5-25 \%$ & $26-50 \%$ & $>50 \%$ \\
\hline
\end{tabular}

Notes: *Nuclear and cytoplasmic markers; ** nuclear marker. Source: Zhong et al. $^{5}$
Table 2 Relationship between lesion grade and histological risk factors

\begin{tabular}{|l|l|l|l|l|}
\hline \multirow{2}{*}{ Lesion grade } & & Low grade & High grade & \multirow{2}{*}{$p$} \\
\cline { 3 - 4 } & & $\mathbf{n ~ ( \% )}$ & $\mathbf{n ~ ( \% )}$ & \\
\hline \multirow{2}{*}{ GI } & Yes & $0(0)$ & $19(22.9 \%)$ & \multirow{2}{*}{0.018} \\
\cline { 2 - 4 } & No & $15(18.1)$ & $49(59)$ & \\
\hline \multirow{2}{*}{ PM } & Yes & $1(1.7)$ & $1(36.2)$ & \multirow{2}{*}{0.039} \\
\cline { 2 - 4 } & No & $10(17.2)$ & $26(46.8)$ & \\
\hline
\end{tabular}

Abbreviations: $\mathrm{Gl}$, glandular invasion; PM, positive margins.

(OR: 4.44; 95\%CI: $1.40-14.06 ; p=0.019$ ). Data are listed on - Table 3.

When the expressions of p16 and $\mathrm{K}_{\mathrm{i}}-67$, isolated or combined, were evaluated considering the same risk factors, disregarding the presence or absence of recurrence, a significant correlation was only found on $\mathrm{p} 16$ positive in HG lesions (OR: 4.713; 95\%CI: 1.091-20.23; $p=0.018$, - Table 4).

Specifically analyzing HG lesions that were $\mathrm{p} 16 / \mathrm{K}_{\mathrm{i}}-67$ positive $(2+$ and $3+)$, comparing the presence/absence of recurrence, a significant difference was found (OR: 0.19; 95\% CI: $0.054-0.662 ; p=0.010$ ); however the percentage of positive cells was higher in the HG group with no recurrence. The other variables were not significant (-Table 5).

\section{Discussion}

Most studies with biomarkers are limited to the correlation between percentage positivity and the presence and grading of pre-invasive lesions; nonetheless, few relate them to the recurrence of these lesions. ${ }^{6}$ No literature was found with the same specific characteristics of this study. Therefore, the findings of this study were compared with each risk factor for which the markers were measured.

The group sample had a significant number of HIV+ patients (31.4\%), and it is known that this pathology is directly related to CIN recurrence, mainly when there is a decrease in $\mathrm{CD} 4+$, indicating low immunity and a poor control of the disease. ${ }^{7-9}$ In the present study, it was observed that HIV + women had a higher recurrence of CIN than HIVwomen (52.9\% and $26.1 \%$ respectively; $p=0.033$ ). This finding is similar to that of Pantanowitz, ${ }^{10}$ who found $50 \%$ recurrence rates for high-grade squamous intraepithelial lesion (HSIL) and $75 \%$ for low-grade squamous intraepithelial lesion (LSIL) over a 6-month period evaluation. Russomano et $\mathrm{al}^{11}$ reported similar results, suggesting that CIN recurrence is $42 \%$ higher in HIV + women. Tebeu et $\mathrm{al}^{8}$ described the same findings in a meta-analysis study that evaluated the number of CIN recurrences in HIV+ women undergoing LEEP with clear surgical margins, in which the recurrence rate was of $20-75 \%$. As in this study, they concluded that the presence of the HIV is a risk factor for CIN recurrence, even in the absence of any other important factors, such as compromised margins.

There was no significant increase of p16 expression in HSIL in women who were HIV + compared with those who were 
Table 3 Relationship between risk factors and recurrence of CIN

\begin{tabular}{|c|c|c|c|c|c|}
\hline \multirow[t]{2}{*}{ Variables } & & \multirow[t]{2}{*}{ Cases n (\%) } & \multicolumn{2}{|c|}{ Recurrence n (\%) } & \multirow[t]{2}{*}{$p$} \\
\hline & & & Yes & No & \\
\hline \multirow[t]{2}{*}{ HIV } & Negative & $59(68.6)$ & $8(9.3)$ & $51(59.3)$ & \multirow[t]{2}{*}{$0.033^{*}$} \\
\hline & Positive & $27(31.4)$ & 9 (10.5) & $18(20.9)$ & \\
\hline \multirow[t]{2}{*}{ Lesion grade } & LG & $17(19.8)$ & $3(3.50)$ & $14(16.3)$ & \multirow[t]{2}{*}{1.000} \\
\hline & $\mathrm{HG}$ & $69(80.2)$ & $14(16.3)$ & $55(64)$ & \\
\hline \multirow[t]{2}{*}{ Glandular invasion } & Yes & $19(22.1)$ & $8(9.6)$ & $11(13.3)$ & \multirow[t]{2}{*}{$0.019^{* *}$} \\
\hline & No & $64(74.4)$ & $9(10.8)$ & $55(66.3)$ & \\
\hline \multirow[t]{2}{*}{ Positive margins } & Yes & $22(25.5)$ & $8(13.8)$ & $14(24.1)$ & \multirow[t]{2}{*}{0.089} \\
\hline & No & 36 (41.9) & $6(10.3)$ & $30(51.7)$ & \\
\hline
\end{tabular}

Abbreviations: CIN, cervical intraepithelial neoplasia; HIV, human immunodeficiency virus; LG, low-grade; HG, high-grade.

Notes: ${ }^{*}$ OR: 0.31 ; $95 \% \mathrm{Cl}: 0.135-0.937 ;{ }^{* *} \mathrm{OR}: 4.44 ; 95 \% \mathrm{Cl}: 1.40-14.06$.

HIV-, and that corroborates the findings of Nicol et al., ${ }^{12}$ who reported that the co-infection of HPV/HIV may result in alterations in the cervical cytokine profile, including factors such as interleukin-6, resulting in the decreased expression of p16. Although seropositivity for HIV has been proved to be a risk factor for recurrence, ${ }^{10,13-15}$ the cervical lesions that recurred have not expressed more biomarkers in HIV+ women than in HIV- women $(p=0.424)$, showing that the markers cannot demonstrate if HIV + women are more prone to recurrence.

Kodampur et $\mathrm{al}^{16}{ }^{16}$ in a cohort study of 309 women with highgrade CIN who underwent LEEP, confirmed the increased need for further intervention when there was endocervical glandular involvement $(p=0.024)$, which is similar to our findings. Glandular involvement is closely related to HSIL, ${ }^{17}$ and it was positively related to recurrence in the samples $(p=0.019)$, which corroborates the findings of Güdücü et $\mathrm{al}^{18}{ }^{18}$ who observed that glandular extension is more present in HG lesions, thus demanding greater care when monitoring these cases.

A relationship was found between the histological risk factors, glandular involvement and compromised margins, to the high grade lesions ( $p=0.018$ and 0.039 respectively), confirming the severity and greater care that these lesions require. Similar results were found by Kir et al (2012), ${ }^{17}$ who suggested a greater attention to the treatment of HG lesions whenever such risk factors were observed.

Jin et $\mathrm{al}^{19}$ compared groups with CIN recurrence after LEEP (348 cases and 1,608 controls), and found that glandular involvement and positive surgical margins increased the risk of relapse. The glandular extension has shown to be a

Table 4 Risk factors of CIN recurrence and relationship with biomarkers

\begin{tabular}{|c|c|c|c|c|c|c|c|c|c|c|}
\hline & & \multicolumn{2}{|c|}{ p16 n (\%) } & \multirow[t]{2}{*}{$p$} & \multicolumn{2}{|c|}{$\mathrm{K}_{\mathrm{i}}-67 \mathrm{n}(\%)$} & \multirow[t]{2}{*}{$p$} & \multicolumn{2}{|c|}{$\mathrm{p} 16 / \mathrm{K}_{\mathrm{i}}-67 \mathrm{n}(\%)$} & \multirow[t]{2}{*}{$p$} \\
\hline & & Neg. & Pos. & & Neg. & Pos. & & Neg. & Pos. & \\
\hline \multirow[t]{2}{*}{ HIV } & Neg. & $\begin{array}{l}9 \\
(10.5)\end{array}$ & $\begin{array}{l}50 \\
(58.1)\end{array}$ & \multirow[t]{2}{*}{1.000} & $\begin{array}{l}3 \\
(3.5)\end{array}$ & $\begin{array}{l}56 \\
(65.1)\end{array}$ & \multirow[t]{2}{*}{0.252} & $\begin{array}{l}4 \\
(4.7)\end{array}$ & $\begin{array}{l}23 \\
(26.5)\end{array}$ & \multirow[t]{2}{*}{0.199} \\
\hline & Pos. & $\begin{array}{l}4 \\
(4.7)\end{array}$ & $\begin{array}{l}23 \\
(26.7)\end{array}$ & & $\begin{array}{l}5 \\
(5.8)\end{array}$ & $\begin{array}{l}22 \\
(25.6)\end{array}$ & & $\begin{array}{l}3 \\
(3.5)\end{array}$ & $\begin{array}{l}56 \\
(65.1)\end{array}$ & \\
\hline \multirow[t]{2}{*}{ PM } & Yes & $\begin{array}{l}2 \\
(3.4)\end{array}$ & $\begin{array}{l}20 \\
(34.5)\end{array}$ & \multirow[t]{2}{*}{0.697} & $\begin{array}{l}2 \\
(3.4)\end{array}$ & $\begin{array}{l}20 \\
(34.4)\end{array}$ & \multirow[t]{2}{*}{0.697} & $\begin{array}{l}1 \\
(1.7)\end{array}$ & $\begin{array}{l}31 \\
(53.4)\end{array}$ & \multirow[t]{2}{*}{0.235} \\
\hline & No & $\begin{array}{l}6 \\
(10.3)\end{array}$ & $\begin{array}{l}30 \\
(51.7)\end{array}$ & & $\begin{array}{l}6 \\
(10.3)\end{array}$ & $\begin{array}{l}30 \\
(51.8)\end{array}$ & & $\begin{array}{l}6 \\
(10.3)\end{array}$ & $\begin{array}{l}20 \\
(34.4)\end{array}$ & \\
\hline \multirow[t]{2}{*}{$\mathrm{Gl}$} & Yes & $\begin{array}{l}1 \\
(1.2)\end{array}$ & $\begin{array}{l}18 \\
(21.7)\end{array}$ & \multirow[t]{2}{*}{0.280} & $\begin{array}{l}1 \\
(1.2)\end{array}$ & $\begin{array}{l}18 \\
(21.6)\end{array}$ & \multirow[t]{2}{*}{0.675} & $\begin{array}{l}1 \\
(1.2)\end{array}$ & $\begin{array}{l}18 \\
(21.7)\end{array}$ & \multirow[t]{2}{*}{0.314} \\
\hline & No & $\begin{array}{l}12 \\
(14.5)\end{array}$ & $\begin{array}{l}52 \\
(62.7)\end{array}$ & & $\begin{array}{l}7 \\
(8.4)\end{array}$ & $\begin{array}{l}57 \\
(68.6)\end{array}$ & & $\begin{array}{l}6 \\
(7.2)\end{array}$ & $\begin{array}{l}58 \\
(69.9)\end{array}$ & \\
\hline LG & & $\begin{array}{l}6 \\
(7.0)\end{array}$ & $\begin{array}{l}11 \\
(12.8)\end{array}$ & \multirow[t]{2}{*}{$0.018^{*}$} & $\begin{array}{l}3 \\
(3.5)\end{array}$ & $\begin{array}{l}14 \\
(16.3)\end{array}$ & \multirow[t]{2}{*}{0.189} & $\begin{array}{l}3 \\
(3.5)\end{array}$ & $\begin{array}{l}14 \\
(16.3)\end{array}$ & \multirow[t]{2}{*}{0.189} \\
\hline $\mathrm{HG}$ & & $\begin{array}{l}7 \\
(8.1)\end{array}$ & $\begin{array}{l}62 \\
(72.1)\end{array}$ & & $\begin{array}{l}5 \\
(5.8)\end{array}$ & $\begin{array}{l}64 \\
(74.5)\end{array}$ & & $\begin{array}{l}4 \\
(4.7)\end{array}$ & $\begin{array}{l}65 \\
(75.6)\end{array}$ & \\
\hline
\end{tabular}

Abbreviations: CIN, cervical intraepithelial neoplasia; GI, glandular invasion; HG, high-grade; HIV, human immunodeficiency virus; LG, low-grade; Neg., negative; PM, positive margins; Pos., positive.

Note: ${ }^{*}$ OR: 4.713; 95\%Cl: 1.09-20.23. 
Table 5 Relationship between recurrence and p16/K $\mathrm{K}_{\mathrm{i}}-67$ expression (positive $2+$ and $3+$ ) and risk factors

\begin{tabular}{|c|c|c|c|}
\hline \multirow[t]{2}{*}{ Risk factor } & \multicolumn{2}{|c|}{ Recurrence n (\%) } & \multirow[t]{2}{*}{$p$} \\
\hline & Yes & No & \\
\hline \multicolumn{4}{|c|}{ High-grade lesion } \\
\hline \multicolumn{4}{|c|}{ p16/K $\mathrm{K}_{\mathrm{i}}-67$ positive } \\
\hline Yes & $5(7.2)$ & $41(59.4)$ & \multirow[t]{2}{*}{$0.010^{*}$} \\
\hline No & $9(13)$ & $14(20.3)$ & \\
\hline \multicolumn{4}{|c|}{ HIV presence } \\
\hline \multicolumn{4}{|c|}{ p16/Ki-67 positive } \\
\hline Yes & $3(11.1)$ & $10(37)$ & \multirow[t]{2}{*}{0.420} \\
\hline No & $6(22.2)$ & $8(29.6)$ & \\
\hline \multicolumn{4}{|c|}{ Positive margins } \\
\hline \multicolumn{4}{|c|}{ p16/K -67 positive } \\
\hline Yes & $3(13.6)$ & $9(40.9)$ & \multirow[t]{2}{*}{0.378} \\
\hline No & $5(22.7)$ & $5(22.7)$ & \\
\hline \multicolumn{4}{|c|}{ Glandular Involvement } \\
\hline \multicolumn{4}{|c|}{$\mathrm{P} 16 / \mathrm{K}_{\mathrm{i}}-67$ positive } \\
\hline Yes & $5(26.3)$ & $9(47.4)$ & \multirow[t]{2}{*}{0.603} \\
\hline No & $3(15.8)$ & $2(10.5)$ & \\
\hline
\end{tabular}

Abbreviation: HIV, human immunodeficiency virus.

Note: ${ }^{*}$ OR: $0.19 ; 95 \% \mathrm{Cl}$ : 0.054-0.662.

primary risk factor; however, compromised margins were not found to be a reliable predictor of recurrence, as opposed to several studies, ${ }^{20-22}$ and this may be because of the less expressive number of positive margin patients included in this study.

The main question of the current research was whether CIN recurrence could or could not be related to $\mathrm{p} 16$ and $\mathrm{K}_{\mathrm{i}}-67$ positive, data still unknown in literature. A study that resembles this was recently published by Fonseca et al. ${ }^{6}$ They evaluated the markers p16 and p53 in 83 conization specimens, analyzing the recurrence predictors of high-grade CIN. They compared the grade of positive markers with relapse, and concluded that they could not foresee the disease's recurrence after conization. The findings of that paper were supported by the findings of this study, as the presence of $\mathrm{p} 16$ and $\mathrm{K}_{\mathrm{i}}-67$ could not be related to glandular involvement, positive margins or recurrence in the samples, suggesting that the dosage of $\mathrm{p} 16 / \mathrm{K}_{\mathrm{i}}-67$ cannot be seen as effective in predicting the recurrence of these risk factors. A significant relation was found though, between p16 positive and HG lesions, leading to the conclusion that in HG lesions, changes in the cell cycle stand out, and that the increased expression of p16 reflects the subsequent inhibition of the pRb. This inhibition of the pRb induces cell immortalization and transformation, a main factor in the evolution of cancer lesions. The same was observed by Calil et $\mathrm{al}^{23}$ in a study of 174 biopsies of the cervix. A strong positive correlation between the expression of $\mathrm{p} 16$ and the severity of premalignant lesions was found. In contrast, p16 and $\mathrm{K}_{\mathrm{i}}-67(2+$ and $3+)$, analyzed together in HG lesions, were significantly associated with recurrence, suggesting that a strong positive HG lesion protein expression would possibly have higher risks of recurrence and, therefore, more attention should be given to these patients, as opposed to the negative or low expressions $(1+)$, which would be less prone to recurrence.

\section{Conclusion}

The high positivity of $\mathrm{p} 16 / \mathrm{K}_{\mathrm{i}}-67$ was a predictor of recurrence only in patients with $\mathrm{HG}$ lesions, suggesting that patients who fit the profile should be monitored closely. In addition, but independently, the research showed that HIV seropositivity and glandular invasion were recurrence risk factors, and also that compromised margins and glandular involvement are more common in severe lesions.

\section{References}

1 World Health Organization. Comprehensive cervical cancer control: a guide to essential practice. 2nd ed. Geneva: WHO; 2014

2 Tornesello ML, Buonaguro L, Giorgi-Rossi P, Buonaguro FM. Viral and cellular biomarkers in the diagnosis of cervical intraepithelial neoplasia and cancer. BioMed Res Int 2013;2013:519619

3 Brown CA, Bogers J, Sahebali S, Depuydt CE, De Prins F, Malinowski DP. Role of protein biomarkers in the detection of high-grade disease in cervical cancer screening programs. J Oncol 2012; 2012:289315

4 Ikenberg H, Bergeron C, Schmidt D, et al; PALMS Study Group. Screening for cervical cancer precursors with p16/Ki-67 dualstained cytology: results of the PALMS study. J Natl Cancer Inst 2013;105(20):1550-1557

5 Zhong P, Li J, Gu Y, et al. P16 and Ki-67 expression improves the diagnostic accuracy of cervical lesions but not predict persistent high risk human papillomavirus infection with CIN1. Int J Clin Exp Pathol 2015;8(03):2979-2986

6 Fonseca FV, Tomasich FD, Jung JE, Maestri CA, Carvalho NS. The role of P16ink4a and P53 immunostaining in predicting recurrence of HG-CIN after conization treatment. Rev Col Bras Cir 2016; 43(01):35-41

7 Babkina N, Heller DS, Goldsmith LT, Houck KL. Cervical conization for cervical intraepithelial neoplasia (CIN) 2 and 3 in HIV-positive women: a case-control study. J Low Genit Tract Dis 2015;19(02): $110-114$

8 Tebeu PM, Major AL, Mhawech P, Rapiti E. The recurrence of cervical intraepithelial neoplasia in HIV-positive women: a review of the literature. Int J STD AIDS 2006;17(08):507-511

9 Clifford GM, Franceschi S, Keiser O, et al; Swiss HIV Cohort Study. Immunodeficiency and the risk of cervical intraepithelial neoplasia 2/3 and cervical cancer: A nested case-control study in the Swiss HIV cohort study. Int J Cancer 2016;138(07):1732-1740

10 Pantanowitz L. Treatment failure and recurrence of cervical intraepithelial neoplasia in HIV-infected women. Womens Health (Lond) 2010;6(06):781-783

11 Russomano F, Paz BR, Camargo MJ, et al. Recurrence of cervical intraepithelial neoplasia in human immunodeficiency virus-infected women treated by means of electrosurgical excision of the transformation zone (LLETZ) in Rio de Janeiro, Brazil. Sao Paulo Med J 2013;131(06):405-410

12 Nicol AF, Golub JE, eSilva JR, et al. An evaluation of p16(INK4a) expression in cervical intraepithelial neoplasia specimens, including women with HIV-1. Mem Inst Oswaldo Cruz 2012;107(05): 571-577 
13 Keller MJ, Burk RD, Xie X, et al. Risk of cervical precancer and cancer among HIV-infected women with normal cervical cytology and no evidence of oncogenic HPV infection. JAMA 2012;308(04): 362-369

14 Massad LS, Xie X, D'Souza G, et al. Incidence of cervical precancers among HIV-seropositive women. Am J Obstet Gynecol 2015; 212(05):606.e1-606.e8

15 Pantanowitz L, Michelow P. Review of human immunodeficiency virus (HIV) and squamous lesions of the uterine cervix. Diagn Cytopathol 2011;39(01):65-72

16 Kodampur M, Kopeika J, Mehra G, Pepera T, Menon P. Endocervical crypt involvement by high-grade cervical intraepithelial neoplasia after large loop excision of transformation zone: do we need a different follow-up strategy? J Obstet Gynaecol Res 2013;39(01): 280-286

17 Kır G, Karabulut MH, Topal CS, Yılmaz MS. Endocervical glandular involvement, positive endocervical surgical margin and multicentricity are more often associated with high-grade than lowgrade squamous intraepithelial lesion. J Obstet Gynaecol Res 2012; 38(09):1206-1210

18 Güdücü N, Sidar G, Başsüllü N, Türkmen I, Dünder I. Endocervical glandular involvement, multicentricity, and extent of the disease are features of high-grade cervical intraepithelial neoplasia. Ann Diagn Pathol 2013;17(04):345-346

19 Jin J, Li L, Zhang F. Meta-analysis of high risk factors of residue or relapse of cervical intraepithelial neoplasia after conization. J Biol Regul Homeost Agents 2015;29(02):451-458

$20 \mathrm{Kim} \mathrm{TH}$, Han JH, Shin E, Noh JH, Kim HS, Song YS. Clinical implication of p16, Ki-67, and proliferating cell nuclear antigen expression in cervical neoplasia: improvement of diagnostic accuracy for high-grade squamous intraepithelial lesion and prediction of resection margin involvement on conization specimen. J Cancer Prev 2015;20(01):70-77

21 Serati M, Siesto G, Carollo S, et al. Risk factors for cervical intraepithelial neoplasia recurrence after conization: a 10-year study. Eur J Obstet Gynecol Reprod Biol 2012;165(01):86-90

22 Lu HX, Chen YX, Ni J, Wan XY, Lü WG, Xie X. [Study on high risk factors associated with positive margin of cervix conization in patient with cervical intraepithelial neoplasia]. Zhonghua Fu Chan Ke Za Zhi 2009;44(03):200-203

23 Calil LN, Edelweiss MI, Meurer L, Igansi CN, Bozzetti MC. p16 INK4a and Ki67 expression in normal, dysplastic and neoplastic uterine cervical epithelium and human papillomavirus (HPV) infection. Pathol Res Pract 2014;210(08):482-487 